\title{
A preliminary survey of the terrestrial arthropods of the Rosenthal Islands, Antarctica
}

\author{
J.D. Gantz (10) ${ }^{\mathrm{a}}$, Drew E. Spacht $\mathbb{1}^{\mathrm{b}}$ \& Richard E. Lee ${ }^{\mathrm{a}}$ \\ aDepartment of Biology, Miami University, Oxford, OH, USA; ${ }^{b}$ Department of Evolution, Ecology and Organismal Biology, Ohio State \\ University, Columbus, $\mathrm{OH}$, USA
}

\begin{abstract}
The Rosenthal Islands lie along the western edge of the Antarctic Peninsula. They are largely inaccessible and the few research projects in the area have focused on seabird colonies, so nothing has been known about the arthropod fauna on these islands. We conducted a preliminary survey of the arthropods associated with large penguin colonies. We identified two species of Collembola (Cryptopygus antarcticus and Friesea grisea), four species of mites (Alaskozetes antarcticus, Hydrogamasellus racovitzai, Tectopenthalodes villosus and Rhagidia sp.) and one insect (Belgica antarctica). The mite $A$. antarcticus and the collembolan C. antarcticus were common in large aggregations at our collecting sites and were occasionally observed on the surface of penguin guano without vegetative cover. The insect, a chironomid midge, was less common and found only in vegetated areas.
\end{abstract}

\section{KEYWORDS}

Antarctic Peninsula;

maritime Antarctic;

Collembola; mites; Belgica

antarctica

\section{Introduction}

The purpose of this survey was to examine arthropod diversity and abundance in the Rosenthal Islands, which lie within the Antarctic Specially Managed Area No. 7 and are under consideration for designation as an Antarctic Specially Protected Area. The Rosenthal Islands $\left(64^{\circ} 35^{\prime} \mathrm{S}, 64^{\circ} 16^{\prime} \mathrm{W}\right)$ lie on the western edge of the Antarctic Peninsula, along the west coast of Anvers Island (Fig. 1). Despite their proximity to Palmer Station, the Rosenthal Islands remain largely inaccessible for scientific study on account of incomplete bathymetry records, many shoals and large swells that make boating difficult. As a result, nothing was known about the arthropods of these islands prior to this survey.

Because the Rosenthal Islands are near Palmer Station $\left(64^{\circ} 46^{\prime} \mathrm{S}, 64^{\circ} 03^{\prime} \mathrm{W}\right)$, where the flora and fauna are well characterized, one might assume that the terrestrial arthropod fauna is similar; however, climatic conditions may be quite different between the two locations. Whereas the area around Palmer Station is sheltered by Cape Monaco from the swell and storms coming from the Drake Passage, the Rosenthal Islands are not protected, are geographically closer to the open ocean where storms circulate along the Antarctic Circumpolar Current (Hoskins \& Hodges 2005) and, as a result, likely experience more wind and precipitation. While there are no climate data available for the Rosenthal Islands to test this assertion, snow cover and depth during our survey was more extensive than it was near Palmer Station at the same time. Indeed, only a small fraction of the land on the islands surveyed in this study was free of snow and ice.

Further, extensive snow cover, along with seabird activity, likely affect the diversity and abundance of arthropod species in the Rosenthal Islands through their influence on vegetative growth. Nearly all the exposed land on the islands included in this survey is used by nesting seabirds (W.R. Fraser, pers. comm. 2017), which can prevent plant growth through trampling and the toxicity of guano (Ryan \& Watkins 1989; Sinclair et al. 2006; Smykla et al. 2007; Schaefer et al. 2017). Virtually all the islands near Palmer Station support moss beds, the terrestrial alga Prasiola crispa (Lightfoot) Kützing 1843 and Antarctic hair grass Deschampsia antarctica E. Desv. (Strong 1967), the vegetation we found in the Rosenthal Islands was largely restricted to steep ridges and small, isolated rock outcroppings without nesting seabirds. What is known about the vegetation on the islands that we did not visit was gleaned from satellite imagery (C. Harris, pers. comm. 2017). Gerlache Island, the largest of the Rosenthal group, is nearly $100 \%$ glaciated; the other islands are not glaciated and many are at least partially vegetated. Though some Antarctic arthropods can live in habitats without vegetation (Gressitt 1967; Strong 1967; Sinclair 2001), vegetative cover mitigates problems with water availability, which is the limiting factor for habitat selection on the Antarctic Peninsula (Janetschek 1970; Kennedy 1993; Convey et al. 2003; 


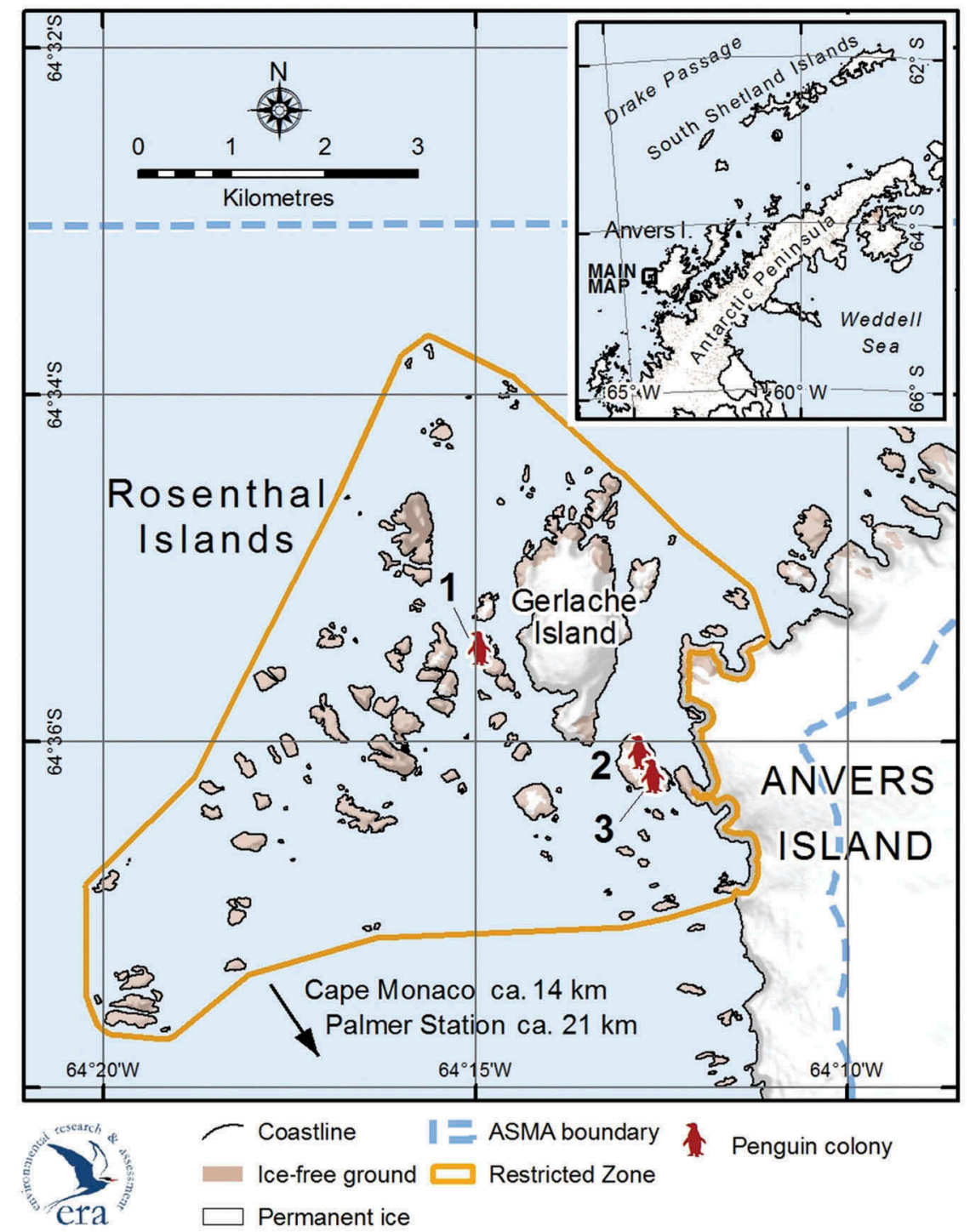

Figure 1. Map of the Rosenthal Islands. GPS waypoints for the three islands surveyed: Island 1: S 64.59079, W 064.24715; Island 2: S 64.60035, W 064.21499; Island 3: S 64.60297W, 064.21044.

Hayward et al. 2004). As such, vegetative cover is an important factor influencing arthropod diversity and abundance in the maritime Antarctic (Worland \& Block 1986; Ryan \& Watkins 1989).

The extensiveness of our survey was severely limited by time and circumstance. Our ship's schedule gave us an $18 \mathrm{~h}$ window in which to work. Poor weather reduced that window to just $8 \mathrm{~h}$, mostly during the late evening and extended twilight hours of the polar summer. Further, the only three islands we were able to visit support penguin colonies, whereas most of the remaining 40 or more islands that make up the Rosenthal group do not. Thus, this note represents only a limited survey of arthropods found on islands heavily used by penguins.

\section{Materials and methods}

The Rosenthal Islands are located about $21 \mathrm{~km}$ northwest of Palmer Station, along the western coast of Anvers Island (Fig. 1). GPS locations for each of the islands surveyed are: Island 1: S $64.59079 \mathrm{~W}$ 064.24715; Island 2: S $64.60035 \mathrm{~W} 064.21499$; and Island 3: S $64.60297 \mathrm{~W} 064.21044$.

The survey was conducted on islands 1, 2 and 3 on 13 December 2016. Surveys were restricted to spotchecking habitats that seemed most likely to support arthropods. These locations generally fit into one of two categories: along the edge of seabird colonies (where special attention was paid to ornithogenic soil under rocks), and areas with moss and $P$. crispa that were unused by or inaccessible to nesting seabirds. Time constraints prevented us from surveying intertidal zones, which are a preferred habitat of at least one species of mite, Rhombognathus gressitti Newell, found in the maritime Antarctic (Strong 1967).

We used aspirators to collect at least five individuals from each distinct species observed in the field. We also sampled large aggregations by collecting substrate from within the aggregation. These samples were returned to our laboratory at Palmer Station, 
where arthropods were separated from the substrate using a modified Berlese extraction (Kawarasaki et al. 2013). Substrate was placed on screens above metal trays filled with ice water. Heat lamps were then placed above the screens and, as the substrate dried, the arthropods moved downward, falling through the screen into the ice water. Following extraction, stereoscopic microscopes were used to help with identification. Sample collection was not standardized and cannot be used to estimate abundance.

\section{Results}

\section{Collembola}

Collembola were present in numerous aggregations of thousands of adults and sub-adults on each of the three islands (Table 1). Cryptopygus antarcticus Willem, 1901 predominated in these aggregations, though Friesea grisea Schaffer, 1891 was present in smaller numbers. Aggregations were found in mosses and $P$. crispa, under rocks, and even on the surface of guano in active penguin colonies where no vegetation was present.

\section{Mites}

Mites were also abundant at our collecting sites, with Alaskozetes antarcticus Michael, 1903 as the dominant species. This common mite was present at all of our sample sites, including in penguin guano without vegetation (Table 1). Other mites Hydrogamasellus racovitzai Trouessart, 1903, Tectopenthalodes villosus Trouessart, 1902, and Rhagidia sp. (either R. gerlachei or R. leechi) were only found on islands 2 and 3 and where moss or P. crispa were present.

\section{Insects}

The chironomid midge, Belgica antarctica Jacobs, 1900 is abundant near Palmer Station and is the only insect found in the area (Strong 1967). We observed midge larvae in modest numbers (fewer than 100 in each location) in one location each on islands 2 and 3 (Table 1). Larvae were only found in moss and P. crispa. The collection site on island 2 was an abandoned section of a penguin colony, about $10 \mathrm{~m} \times 5 \mathrm{~m}$ in size. It is unclear how long this area was unused, though vegetation was sparse and mainly restricted to sheltered spaces among rocks, suggesting that the substrate remained too toxic to support much vegetation. The site on island 3 was on a cliff face about $10 \mathrm{~m}$ high on the leeward side of the island that was too steep for seabirds to use for nesting. Moss and P. crispa grew on small ledges, usually less than $15 \mathrm{~cm}$ wide, across the cliff face. Every other species of arthropod we identified was also present in both of these locations.

\section{Discussion}

The results of our survey indicate that some of the arthropods commonly found on the sheltered and vegetated islands around Palmer Station also thrive in the harsher conditions of the Rosenthal Islands. Indeed, the two most abundant species in the maritime Antarctic (Tilbrook 1967; Block \& Convey 1995; Hogg \& Stevens 2002) occurred in aggregations of thousands of individuals. Though the collembolan C. antarcticus and the mite A. antarcticus were abundant, their distribution was patchy and there were no obvious reasons for their presence or absence in many of the survey sites. This uneven distribution might be explained by clumping due to social factors, rather than limitations of seemingly identical microhabitats (Joosse \& Groen 1970; Booth \& Usher 1984; Usher \& Booth 1986). Additionally, the variety of habitats occupied by C. antarcticus and A. antarcticus supports the idea that these are generalists that tolerate a wide variety of environmental insults (Richard et al. 1994). Low temperature, particularly, does not appear to be a limiting factor for survival in the Rosenthal Islands because these, and other, species

Table 1. The islands and habitat types where each species of arthropod was identified in the Rosenthal Islands. N/A denotes the absence of that habitat type found on the island.

\begin{tabular}{|c|c|c|c|c|}
\hline Island & Substrate type & Acari & Collembola & Insecta \\
\hline \multirow[t]{2}{*}{1} & Ornithogenic soil, no vegetation & A. antarcticus & $\begin{array}{l}\text { C. antarcticus } \\
\text { F. grisea }\end{array}$ & \\
\hline & Vegetated & $\mathrm{N} / \mathrm{A}$ & $\mathrm{N} / \mathrm{A}$ & N/A \\
\hline \multirow[t]{2}{*}{2} & Ornithogenic soil, no vegetation & $\begin{array}{l}\text { A. antarcticus } \\
\text { H. racovitzai }\end{array}$ & $\begin{array}{l}\text { C. antarcticus } \\
\text { F. grisea }\end{array}$ & \\
\hline & Vegetated & $\begin{array}{l}\text { A. antarcticus } \\
\text { H. racovitzai } \\
\text { T. villosus }\end{array}$ & $\begin{array}{l}\text { C. antarcticus } \\
\text { F. grisea }\end{array}$ & B. antarctica \\
\hline \multirow[t]{2}{*}{3} & Ornithogenic soil, no vegetation & $\begin{array}{l}\text { A. antarcticus } \\
\text { H. racovitzai }\end{array}$ & $\begin{array}{l}\text { C. antarcticus } \\
\text { F. grisea }\end{array}$ & \\
\hline & Vegetated & $\begin{array}{l}\text { A. antarcticus } \\
\text { H. racovitzai } \\
\text { T. villosus } \\
\text { Rhagidia sp. }\end{array}$ & $\begin{array}{l}\text { C. antarcticus } \\
\text { F. grisea }\end{array}$ & B. antarctica \\
\hline
\end{tabular}


are widely distributed in colder areas further south along the Antarctic Peninsula (Convey \& Smith 1997; Convey 1998; Stevens \& Hogg 2002).

Interestingly, $C$. antarcticus, and A. antarcticus, were both common on the surface of penguin guano in active parts of the penguin colonies. While it is not uncommon to find these species in similar locations elsewhere (Strong 1967), they are typically under rocks and, despite extensive collecting, we have never observed large aggregations on the surface of guano at Palmer Station. It is possible that the timing of our survey could explain this behaviour. The surveys were conducted from approximately 18:00 until 02:00 (local time), which includes a few hours of twilight. Perhaps the observed behaviour is common during the overnight hours when we would not normally be out collecting to see it; however, this seems unlikely because many aggregations were noted on penguin guano early in the survey, well before sunset. Instead, since arthropods select habitats under rocks to mitigate water stress (Strong 1967), this behaviour was more likely the result of high relative humidity and moisture content in the substrate resulting from recent precipitation, reducing or eliminating the need for water-conserving behaviour.

With the exception of $C$. antarcticus, and A. antarcticus, the other arthropods we identified in this study were restricted to habitats with vegetation. This could be because vegetative cover can help retain water and water availability, not cold, is the limiting factor for arthropods in the maritime Antarctic (Kennedy 1993; Convey et al. 2003; Hayward et al. 2004). Cryptopygus antarcticus and A. antarcticus may behaviourally overcome the limitations presented by hydric stress in non-vegetated sites by seeking moist refuges during periods of hydric stress (Hayward et al. 2001; Hayward et al. 2004) and forming aggregations, which enhances resistance to desiccation (Benoit et al. 2008).

Our preliminary results show that the arthropod diversity of the Rosenthal Islands is similar to that of Palmer Station. Even so, we observed unusual habitat usage by $C$. antarcticus, and $A$. antarcticus, as both species were abundant in areas without vegetative cover, and were struck by how different these islands were from those close to Palmer Station.

\section{Acknowledgements}

The authors would like to thank Colin Harris and Katharina Lorenz of Environmental Research and Assessment for contributing the map in Fig. 1. We would also like to thank the support staff at Palmer Station, in particular the small boat operations team, for their hard work and assistance as well as the captain and crew of the Laurence M. Gould, who provided logistic support and expertly coordinated the field visit.

\section{Disclosure statement}

No potential conflict of interest was reported by the authors.

\section{Funding}

This research was supported by US National Science Foundation grant no. PLR 1341385.

\section{ORCID}

J.D. Gantz (D) http://orcid.org/0000-0003-3847-6031

Drew E. Spacht (i) http://orcid.org/0000-0002-3651-114X

\section{References}

Benoit J.B., Yoder J.A., Lopez-Martinez G., Elnitsky M.A., Lee R.E. \& Denlinger D.L. 2008. Adaptations for the maintenance of water balance by three species of Antarctic mites. Polar Biology 31, 539-547.

Block W. \& Convey P. 1995. The biology, life cycle and ecophysiology of the Antarctic mite Alaskozetes antarcticus. Journal of Zoology 236, 431-449.

Booth R.G. \& Usher M.B. 1984. Arthropod communities in a maritime Antarctic moss-turf habitat: effects of the physical and chemical environment. The Journal of Animal Ecology 53, 879-893.

Convey P. 1998. Latitudinal variation in allocation to reproduction by the Antarctic oribatid mite, Alaskozetes antarcticus. Applied Soil Ecology 9, 93-99.

Convey P., Block W. \& Peat H.J. 2003. Soil arthropods as indicators of water stress in Antarctic terrestrial habitats? Global Change Biology 9, 1718-1730.

Convey P. \& Smith R.I.L. 1997. The terrestrial arthropod fauna and its habitats in northern Marguerite Bay and Alexander Island, maritime Antarctic. Antarctic Science 9, 12-26.

Gressitt J.L. 1967. Notes on arthropod populations in the Antarctic Peninsula-South Shetland Islands-South Orkney Islands area. In J.L. Gressitt (ed.): Entomology of Antarctica. Pp. 373-391. Washington, D.C.: American Geophysical Union.

Hayward S.A.L., Bale J.S., Worland M.R. \& Convey P. 2001. Influence of temperature on the hygropreference of the collembolan, Cryptopygus antarcticus, and the mite, Alaskozetes antarcticus from the maritime Antarctic. Journal of Insect Physiology 47, 11-18.

Hayward S.A.L., Worland M.R., Convey P. \& Bale J.S. 2004. Habitat moisture availability and the local distribution of the Antarctic Collembola Cryptopygus antarcticus and Friesea grisea. Soil Biology and Biochemistry 36, 927-934.

Hogg I.D. \& Stevens M.I. 2002. Soil fauna of Antarctic coastal landscapes. In L. Beyers \& M. Bölter (eds.): Geoecology of Antarctic ice-free coastal landscapes. Pp. 265-280. Berlin: Springer.

Hoskins B.J. \& Hodges K.I. 2005. A new perspective on Southern Hemisphere storm tracks. Journal of Climate $18,4108-4129$.

Janetschek H. 1970. Environments and ecology of terrestrial arthropods in the High Antarctic. In M.W. Holdgate (ed.): Antarctic ecology. Vol. 2. Pp. 871-885. New York: Academic Press.

Joosse E.N. \& Groen J.B. 1970. Relationship between saturation deficit and the survival and locomotory 
activity of surface dwelling Collembola. Entomologia Experimentalis et Applicata 13, 229-235.

Kawarasaki Y., Teets N.M., Denlinger D.L. \& Lee R.E. 2013. The protective effect of rapid cold-hardening develops more quickly in frozen versus supercooled larvae of the Antarctic midge, Belgica Antarctica. Journal of Experimental Biology 216, 3937-3945.

Kennedy A.D. 1993. Water as a limiting factor in the Antarctic terrestrial environment: a biogeographical synthesis. Arctic and Alpine Research 25, 308-315.

Richard K.J., Convey P. \& Block W. 1994. The terrestrial arthropod fauna of the Byers Peninsula, Livingston Island, South Shetland Islands. Polar Biology 14, 371379.

Ryan P.G. \& Watkins B.P. 1989. The influence of physical factors and ornithogenic products on plant and arthropod abundance at an inland nunatak group in Antarctica. Polar Biology 10, 151-160.

Schaefer C.E., Pereira T.T., Almeida I.C., Michel R.F., Corrêa G.R., Figueiredo L.P. \& Ker J.C. 2017. Penguin activity modify the thermal regime of active layer in Antarctica: a case study from Hope Bay. Catena 149, 582-591.

Sinclair B.J. 2001. On the distribution of terrestrial invertebrates at Cape Bird, Ross Island, Antarctica. Polar Biology 24, 394-400.
Sinclair B.J., Scott M.B., Klok C.J., Terblanche J.S., Marshall D.J., Reyers B. \& Chown S.L. 2006. Determinants of terrestrial arthropod community composition at Cape Hallett, Antarctica. Antarctic Science 18, 303-312.

Smykla J., Wołek J. \& Barcikowski A. 2007. Zonation of vegetation related to penguin rookeries on King George Island, maritime Antarctic. Arctic, Antarctic, and Alpine Research 39, 143-151.

Stevens M.I. \& Hogg I.D. 2002. Expanded distributional records of Collembola and Acari in southern Victoria Land, Antarctica. Pedobiologia 46, 485-495.

Strong J. 1967. Ecology of terrestrial arthropods at Palmer Station, Antarctic Peninsula. In J.L. Gressitt (ed.): Entomology of Antarctica. Pp. 357-371. Washington, D.C.: American Geophysical Union.

Tilbrook P.J. 1967. The terrestrial invertebrate fauna of the maritime Antarctic. PhilosophicalTransactions of the Royal Society of London, Series B, Biological Sciences 252, 261-278.

Usher M.B. \& Booth R.G. 1986. Arthropod communities in a maritime Antarctic moss-turf habitat: multiple scales of pattern in the mites and Collembola. The Journal of Animal Ecology 55, 155-170.

Worland M.R. \& Block W. 1986. Survival and water loss in some Antarctic arthropods. Journal of Insect Physiology 32, $579-584$. 